\title{
ORGANISATION OF PUBLIC SERVICE IN RUSSIA IN THE MODERN PERIOD: SEEKING A NEW QUALITY OF MANAGEMENT
}

\author{
Yevgeny Okhotsky* \\ Vladimir Beryozko ${ }^{\star *}$
}

DOI 10.24833/2073-8420-2017-4-45-36-46
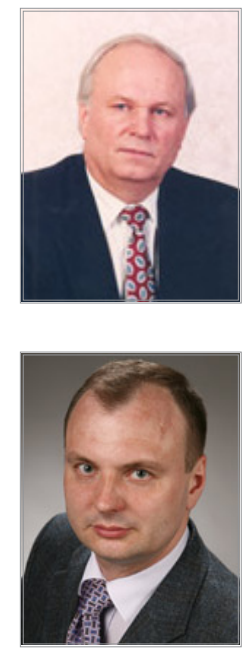

Introduction. This article represents a system analysis of the most important characteristics and organisational principles of public service in today's Russia and a number of foreign countries in the context of the existing realities and prospective structural, management and staff reform in the government system. The article describes the key elements characterising the organisational aspect of public service. It is emphasised that government modernisation has a particular importance for the current reality, primarily due to the fact that it is undertaken during a critical historical period for the Russian society. This entails the task to provide public servants with the modern "culture of changes", which would enable them not to destroy, but to create and improve, while retaining the best achievements accumulated during the history of state-building and public administration, and to activate any new and more efficient model by means of a smooth and creative, rather than revolutionary and disintegrating, process of transition.

The authors have defined the notion "organisation of public service" and identified a number of organisationally and functionally interrelated subsystems therein, and they prove that only a stable, well-structured and high-skilled government staff and a highly efficient, well-organised and reputable public service can implement efficiently the tasks of modernisation and social renewal. The public service is a multidimensional space where each element has its own status, distinctive features and attributes, as established in the relevant national enactments and regional regulations. It is characterised by a number of specific features. First of all, it can be described as the institution of universal legal regulations to be complied with in an indisputable manner, and the professional service activity directly associated with the exercise of the state's powers; it is established on a permanent, professional and paid basis, in accordance with the principles of democracy, legality, focus on social issues and humanism.

Materials and methods. The dialectical materialistic approach towards analysing social phenomena, their legal regulation and strategic managing influence upon them has formed the theoretical and methodological basis for this study. A broad set of methods for scholarly analysis of political and social phenomena was used, including the comparative law, formal logical, specific historical and system functional methods.

\footnotetext{
* Okhotsky, Yevgeny Vasilyevich, Doctor of Sociology, Professor, Department of Public Administration and Law, School of Governance and Politics, MGIMO University of the Russian Ministry of Foreign Relations. e-mail: e.ohotskii@mail.ru.

** Beryozko, Vladimir Eduardovich, Candidate of Law, Associate Professor, Department of Public Administration and Law, School of Governance and Politics, MGIMO University of the Russian Ministry of Foreign Relations. e-mail: vberezko@yandex.ru.
} 
Study results. Within the framework of the "developing approach" and the implementation of the ideas related to the "new culture of public service", the authors have substantiated certain measures for further reform of public service, including the stricter delimitation of powers among instrumentalities and the enhancement of their responsibility; the decentralisation of administrative units, to be more focused on quality and efficiency; the de-bureaucratisation of internal public service and public administration activities; enhancing the prestige of the public servant's profession; upgrading the personnel development system in order to provide employees with stronger motivation for continuous skill development; and updating the structure of remuneration and benefits for public employees.

$\mathrm{P}$ ublic service is the most important component of the mechanism for the formation and exercise of government power. It develops within the overall context of the political, economic, social, spiritual and ethical processes, which occur on both national and global level. It is distinguished by a high degree of legal regulation, professional, spiritual and ethical culture and a high level of staff availability. It is intended to perform in a skilled manner any tasks related to social and economic development; national security, territorial integrity and sovereignty; preservation of the people's cultural, spiritual and ethical independence; protection of the rights, freedoms and lawful interests of citizens; and creation of favourable conditions for the efficient work, decent life and comprehensive development of individuals.

It is clear that such tasks can only be performed by a stable, well-structured and highskilled government staff and a well-organised and highly reputable public service, but in no way by the bureaucrats, who were described by the Russian President in one of his addresses to the Federal Assembly as a closed and arrogant caste, which understands public service as a sort of business and which has learned to use power for their own benefit rather than public welfare. Therefore, the President named as strategic task number one "an increase in the efficiency of public administration, strict compliance with law by public servants, and the provision of high-quality public services for individuals" [14]. He also reiterated the goal of developing "an understandable, convenient and comfortable system of interaction between the state and the society and between the state and the citizen" in his Address of March 1, 2018. He put particular emphasis upon the need to digitalise the public administration system, to make it more transparent and to motivate officials to "increase their efficiency and to achieve specific results" [13].
The organisation of public service is a form of rationally structured system of legally regulated and internally consistent interaction among relatively autonomous and independent government instrumentalities. It is not a simple linear "set of persons and groups formed for the implementation of a certain government task", but a complex political system institution including a number of subsystems interrelated in organisational and functional terms: a) the staff units of government authorities (departments, divisions, offices, groups, secretariats, positions); b) a system of horizontal and vertical public service relations, rules and regulations, as well as processes and acts, which consolidate public servants for the achievement of their goals; c) a set of statuses and legally established service roles, functions and powers; d) specially structured managing influences (through legally prescribed and practically tested forms, methods, tools and procedures) upon human mentality and behaviour, labour teams, civil society institutions, authorities and the society as a whole.

The specific organisation of public service is determined by the type and historical stage of the relevant society, the form of the state, the prevailing political regime, the established system of public service law, the ethical traditions, culture and mentality of the nation. This results in diverse models of public service's organisational structure and legal regulation, such as the Romano-Germanic (continental), Anglo-Saxon, Soviet labour-based and Islamic models.

The public service of the United Kingdom, for example, is career-based and follows the principles of "new public administration; it is not governed by any specific legislation, and all its aspects are subject to the overall principle that "a minister is responsible to parliament". The organisation of the public service and the career promotion of the staff are free from any current political influence. Recruitment is based on competitive principles, the officials must be 
politically neutral and their promotion will depend upon their personal achievements and merits. The Civil Service Commission and the Civil Service Code play an integrating role.

They are convinced in Hungary, that no public service will be efficient unless it is well-structured in legal terms and based on firm spiritual and ethical principles. So the state focuses not only on professional skills, but on the personal potential as well. Therefore, the public servant is expected to be disciplined and well-balanced, to possess the sense of measure, to be diligent in service-related matters and honest in personal affairs, punctual and responsible for any of his or her words, acts and deeds.

Germany has its own specific features as concerns its model of public service. Many of them are due to the very rich traditions of its bureaucracy, first of all discipline, loyalty to the official duty and national interests, severity, asceticism, and personal responsibility. The federal nature of the state has its material influence. The formation and operation of the public service, the public service career, the staff, information, financial and economic support for the public service are strictly regulated by the federal and land laws, as well as the applicable decrees, charter and regulations.

In the USA, the transition from "top-tobottom" administration towards an "entrepreneurial" government primarily intended to modify the country "from bottom to top" is the integrating idea of the public service. The values of responsibility, competence, political neutrality and discipline form the political basis of public service relations [17. P. 25-26]. Its legal basis is made up by dedicated laws regarding public service, the code of official conduct and the institution of the oath; its principles are legality, democracy, nonpartisanism, social commitment, and the organic nature of public administration and ethics. Some states apply rules regarding the ethical responsibility of officials.

The French model has its own specific features: it encompasses all paid employees of national or municipal agencies, institutions or instrumentalities; the guaranteed employment of public servants; the statutory definition of principles, rights, duties and guarantees with respect to the public service; an effective response to the public needs in accordance with the values of a rule-of-law social state; the priority of the public service consumer's interests; and continuous professional development of the governmental staff.

Anyway, the principal purpose of public service is always the same - "to manage the arrangement and distribution of human and physical resources for the attainment of any desirable (by the government and society) goals [16. P. 3] by implementing appropriate legislative, administrative/management and judicial/ enforcement mandates. And all of this is intended for the optimisation and highly efficient operation of public service as the most important component of the public mechanism for "the consistent application of law" [18. P. 197-222] and the exercise of the state's powers.

Contemporary science has developed the idea of public service as a rather complex, in organisational terms, system of social relations and a social institution of public law regulation. As stated by N.M. Korkunov, there is "a special public law relation of a servant to the state, based on subordination and aimed at certain mandatory activities being conducted on behalf of the state and intended to perform a particular public task". Hence the specific nature of state enforcement is as follows: by monopolising the power of enforcement, the state is required to perform its enforcement functions not only in its own interests, but also in the interests of the society as a whole. In this regard, the government agencies and their employees entrusted with protecting the violated interests of individuals and their associations by force do this in a cool and impassionate manner - the measures of enforcement are "governed not by any emotion prompting violence and not only by the rules of appropriateness but also by the principles of law and morality" [7. P. 30-31].

As the contemporary Russian legislator understands it, public service is any professional service activity of Russian citizens supporting the exercise of the powers of the Russian Federation, federal government authorities and other federal government bodies; the subjects (i.e. regions) of the Russian Federation; the government authorities and other government bodies of the subjects of the Russian Federation; the persons holding any offices established by the Constitution of the Russian Federation or federal laws for exercising directly the powers of any federal government bodies, as well as the persons holding any offices established by the constitutions, statutes or laws of the respective subjects of the Russian Federation for exercising directly the powers of the government bodies of such Russian Federation subjects. The key words of the text above are "professional", "activity" of "citizens" "supporting" the exercise of the powers of the relevant government and administrative authorities.

Some scholars, primarily those who represent political sociology and social management, stress the phrase "professional support" and 
believe that public servants personally do not exercise power and are not involved in active politics and that their competence does not include any direct exercise of the political component of government functions. The mission of such servants is to organise, supervise and provide with resources the implementation of any laws, edicts, resolutions, decisions and other administrative acts of the state. In the opinion of such scholars, the extent of their official powers is rather narrow, being limited to performing purely executive/dispositive, organisational/ administrative, monitoring/supervisory, information analysis, forecasting/advisory and protocol/technical tasks.

The proponents of this concept of public service find it difficult to imagine that public service is not an auxiliary (or all the more servicing) element of the government mechanism, but a system specially created for "the practical and professional participation of citizens in the performance of tasks and functions of government". It is difficult or them to understand that public service is not an auxiliary, administrative or bureaucratic element of public administration, but a most important political institution of public law regulation, the essence of which is "the practical, targeted, organising and regulating influence of citizens in public service upon social processes and the mentality, behaviour and everyday activities of people". This is an institution of "equally available and direct participation of citizens in the affairs of the state". It is created in the interests of the state, personifies the state, serves the state and is controlled by the society and the state [3. P. 87-93; 5 . P. 32; 6. P. 12-13; 8. P. 108-116; 12. P. 125].

And all civilised countries follow this. The constitutions of all democratic states contain a lot of articles covering the issues of public service, from the provisions regarding the sources of governmental power, its values and social actors to the constitutional provisions granting to the citizens the right of equal access to the public service and the provisions regarding the principles and methods for professional implementation of governmental powers [4. P. 233-234].

Of course, it contains a certain element of servicing, because the provision of public services for individuals and legal entities is one of its most important functions, but its political power status and public administration significance are at the core of it. This results in the hierarchical nature of its organisation, the professional and impersonal nature of exercising any official duties, and personnel stability.

A public employee reports to his or her direct supervisor and performs the latter's orders and instructions, but this in no way means that he or she is "in the service" of such supervisor. The key value for the public employee is not his or her effectiveness or bureaucratic diligence, but serving the Law, the Society and the Citizen in a conscious and constructive manner. In this case, the public employee acts not only as a professional manager but also as a public official. The competence of such employee includes the performance of government functions and professional support for the exercise of government powers by any government bodies or persons holding government offices. The public service constitutes a special form of procedural support for the legislative/representative, executive, controlling/regulatory and supervisory functions of the state [11. P. 90-97]. This explains its strict legal regulation and the business-like, flexible and smooth operation of its staff. From this perspective, the public service relations are governed by the rules of constitutional, administrative, financial, customs, tax, banking, pension, international and other branches of public law. By entering the service of the state, a citizen in this framework changes from one status to another, from a specialist manager to a professional administrator within the system of government who expresses and protects the interests of the state.

The public service is characterised by a number of distinctive features. First of all, it is the professional service activity of Russian citizens, which is primarily intended to support, in a professional manner, the exercise of the powers of the Russian Federation and its subjects, the federal authorities and the government authorities of Russian federal subjects, and the powers of any persons holding government offices in the Russian Federation or its subjects. It is the system of practical and professional participation of citizens in implementing the purposes and functions of the state in the form and by means of targeted, organising and regulating influence upon social processes and the mentality, behaviour and activities of people. It arranges for the interaction of three elements: the state, the government body and the government office. It supports the organic unity of law, freedom and enforcement [10. P. 64]. Furthermore, any activities within this system must be proper, necessary and obligatory, irrespective from the desire and will of any person in public service [1. P. 122-125].

This aspect of public administration was specifically examined by $\mathrm{W}$. Wilson, who relied on the ideas and theoretical propositions of Max Weber's rational bureaucracy. As the prevailing features of the governmental bureaucracy, he identified the rational institutional structure 
of the bureaucratic machine, the impersonal and nonpartisan nature of its operations, and the fact that it is intended for solving the most important national problems based on the principles of public interest, legality, professionalism and personal responsibility. He, like G. Hegel before him, considered the bureaucracy to be the key pillar of the state, a specific system through which power was organised and the form of its professional implementation. He also paid attention to three factors intended to ensure that the bureaucracy would never go beyond the limits of "general interest". These are (a) the hierarchical nature of government; (b) the independence of corporations and local communities, which implement and protect the interests of particular social groups; (c) special professional training and upbringing of officials in the spirit of dedication and justice. These principles are still relevant for the public service system, which has developed in democratic, rule-of-law countries. The Russian Federation has borrowed many aspects of public service experience in France, Germany, Canada, the United States, and Japan.

The public service is the system of legal, organisational and procedural institutions exercising government power. It is neither a labour duty within the framework of a certain labour community, nor any part-time or pro bono activity; it is the activity of specially trained, specially selected and duly appointed specialists working on a permanent, professional and paid basis, solely at the expense of the state budget. In this regard, the public service constitutes a special social phenomenon of public law regulation that can also be viewed as the continuous process of exercising official duties on a professional basis in the specific constitutional and administrative law space of public administration activities.

Another determinative attribute of the public service is that it is the activity of government authorities and their employees, which is specially organised and regulated by legal rules in detail. Furthermore, it is a professional activity that is being conducted on a permanent, professional and paid basis. For such employees, the public service is their primary and sole professional (i.e. consistent with their education, professional training and experience) labour activity within their competence established by law. Their principal task is to do, in the name, on behalf and under the control of the state, socially and legally significant acts in relation to specific social relations. In this regard, public service constitutes a special political and legal phenomenon and a system that can be treated as the continuous and well-organised process of professionally exercising certain official duties within the special constitutional and administrative law space of political, legal and public administration activities.

The public service must be implemented solely through federal and regional government bodies, i.e. the staff units of any legislative, executive or judicial bodies, offices of public prosecutors, audit chambers, the Central Election Commission and other election commissions and any official instrumentalities established to support the exercise of their powers by any persons holding public offices, such as presidents, deputies, senators, ministers, judges, public prosecutors, governors and other "top officials". Work for any other state-owned, private, cooperative, non-government organisations, private institutions or businesses, municipal or local government bodies does not constitute public service and is not included in the system of public service.

The public service is directly associated with the process of exercising the powers of the state, government authorities and any persons holding offices within the system of government and public service. Acting within the constitutional system of power separation and federalism, public servants participate in preparing development programmes for their respective fields, industries or territories, perform organisational/dispositive, monitoring/audit, law enforcement and other law application activities, provide public services and arrange for the management of state-owned property.

However, the implementation of the above principle differs from country to country. The United States emphasises the strategic management of human capital development, the enhancement of competition between the public and private sectors, a maximum financial efficiency of the government, and the budgeting of governmental agencies according to their performance. The UK successfully uses a two-tier system of governmental agencies, including governmental policy centres and key administration departments around such centres. Outsourcing and contractual relations with governmental authorities are widely used.

In our opinion, however, there is no valid reason to state that, as management technology develops and the functions of government and business become intertwined, the role of public servants is substantially modified and that public servants are now "more like management consultants or experts, being less different from business managers" [9. P. 35]. There is some sense in such statements, of course. 
But this in no way means that public service is transformed into a kind of service institution. The public service is a tool of public law rather than private law regulation aimed at political, organisational and enforcement support for the implementation of government power. Its basic functions are well-known and remain in place: the setting of goals, analysis and forecasting, programming and planning, organisation and coordination, monitoring and accounting, personnel, information and resource support, the performance and provision of public services.

The public service is an organic body of specialist employees integrated by individual and collective forms of employment on a contractual basis as part of the relevant instrumentalities. Their status, qualifications, rights, duties, legal responsibility, restrictions and prohibitions associated with their service, their guarantees, the procedure for their recruitment and appointment, the system of their training, retraining and development, the procedures and basis for their termination are strictly regulated and determined, in each particular case, by the relevant laws, decrees, statutes, administrative regulations or job descriptions. The other side of this rationality is represented by caste mentality, corporatism, status-related privileges, hierarchical relations, strict discipline, i.e. all those things, which shape the mentality of officials and consolidate them into a well-organised "interest group" capable of exerting a considerable (and not always positive) influence upon the society as a whole.

Of course, this aspect involves a lot of country-specific features as well. The staff pool of the UK public service consists of three components: the core of career employees; employees who serve on a contractual basis; and employees who would be recruited for each specific project and remain within a semi-market framework. In Germany, three classes of public servants constitute the staff: career staff (about 30\%), a sort of professional public administration elite, who enjoy lifetime employment; officers (about 45\%); and hired employees. A specific system of incentives and disciplinary actions is in place. Mexico is different. The public service there is broadly understood and includes the activities of officials holding not only administrative or managerial but also political positions, as well as the administrative staff of the central, provincial and local governments, governmental instrumentalities and public companies. In terms of their status, public servants are divided into basic staff (working in ancillary positions under fixed-term employment contracts) and fiduciary staff (performing complex and critical functions).
The public service is a set of socially and legally regulated relationships among the state, the society and the individual, including the relationships between the state, as employer, and any individuals in its service. This includes the scope, content, conditions, forms, methods and results of service-related activities. Public service is built in the social organism. It closely interacts with all civil society institutions and individual citizens. That is why the key performance criterion of public service is not quantity but quality and effectiveness, i.e. the conformity of its actual performance indicators with the public needs and the approved social standards.

The public service is the institution of universal legal rules and regulations, to be complied with in an indisputable manner, on the basis of legally established principles, such as legality, democracy, federalism, nonpartisanism, openness, morality, and social equality with respect to the access of citizens to public service. Appropriate laws, decrees, codes, resolutions, orders, regulations and instructions define the staffing structure, rights, duties and responsibility of public employees, the procedure for their service and any guarantees, prohibitions and restrictions associated therewith, the procedure for any job-tenders, certifications or qualification examinations, the assignment of positions, ranks and titles etc. And the legal regulation of any powers and functions associated with public service is at the core of it.

The public service is a multidimensional space where each element has its status and its distinctive features and attributes and is defined by the relevant national statutes and regional regulations. There is a single system of public service in the country. But, as regards levels, it is divided into the federal public service and the civil public service in Russian federal subjects. As regards classification by types, it is divided into civil, military and other types. The civil service, in its turn, is divided into the federal civil service and the civil service in Russian federal subjects. According to the separation of power criterion, the public service can be treated as a set of public services in representative/legislative, executive and judicial bodies. The public service has its specific features in terms of its status/position structure as well.

The law-enforcement, taxation, customs, courier, diplomatic and other fields of public service activities are often mentioned. It should be noted, however, that Russian administrative and service law does not define them as separate types of public service, despite that each of them has its quite meaningful distinctive fea- 
tures. According to Federal Law No. 205-FZ, dated July 27, 2010, "On the Special Procedure of Civil Public Service in the Ministry of Foreign Affairs of the Russian Federation", diplomatic service shall (a) be performed solely by persons holding positions in federal civil service; (b) be governed by both the national laws regarding public service and the international laws regarding diplomatic and consular relations, taking into account any laws, customs and regime restrictions applicable in the country of residence; and (c) involves certain additional rights, duties, restrictions, prohibitions, guaranties and qualification requirements with respect to diplomatic positions in accordance with the specific conditions of diplomatic activities. The field of diplomatic relations (d) uses a special procedure for competitive selection, appointment to diplomatic positions, staff rotation and assignment of diplomatic ranks; and (e) includes a special, in structural terms, procurement system for diplomatic employees. In addition, (f) special types of uniform and insignia must be used.

The functions of diplomatic service are governed by the relevant legal regulations. An analysis of international legal practice demonstrates that, although many notions are identical, there exist specific features and nuances with respect to may organisational matters of diplomatic service. The functions of diplomatic service are often confused with the functions of the diplomatic agency and its instrumentalities (Azerbaijan, Georgia, Turkmenistan, Tajikistan). The statutory duties may include such minor details as the duty "to treat every person with respect and courtesy" (Australia), "to know the rules of diplomatic etiquette" (Armenia), "to state any facts or relevant matters in a truthful manner" (UK), or "to refrain from any acts or statements damaging the positive image of the country" (Moldova).

The rights of diplomatic officials in diplomatic law are typically described rather briefly and, as a rule, as a reference to the general legislation regarding public service (Argentina, Armenia, Kazakhstan, Kyrgyzstan). On the contrary, the aspects related to their career, remuneration and social security are set forth in a quite detailed and strict manner. It is especially true as regards the remuneration and salaries of diplomats, state guarantees for the diplomatic staff, personnel development, medical and transportation services, as well as education and employment for a diplomat's family members (Germany, Kazakhstan, Ukraine). Country-specific features also concern the practices of recruitment for diplomatic service, staff assessment qualification tests, the assignment of diplomatic grades, rotation and career regulation. For instance, Armenia does not permit any continuous sequence of assignments to foreign diplomatic institutions, Kazakhstan practices two types of rotation, domestic and international, and Ukraine widely declares the principles of professionalism, scheduled activities and transparency.

This understanding of public service is of fundamental importance for our country. In its current state of transition, Russia can hardly hope to overcome its difficulties without a highly skilled and reputable public service. A strong government results not only from its laws and law-enforcement bodies, but also primarily from its legitimacy, popular support, a high legal culture and the ability of public servants to integrate law, policy and ethics. Hence the key target of public service modernisation is to put together an integral and more flexible system of public service capable of adapting to the rapidly changing political, social and economic environment.

The in-depth social and political meaning of public service is reflected by the system of its principles. They are established by Federal Law No. 58-FZ, dated May 27, 2003, “On the System of Public Service in the Russian Federation":

a) the priority of the rights and freedoms of the human and citizen, the mandatory nature of their recognition, observance and protection;

b) the lawfulness, political and ideological neutrality of public servants;

c) federalism, i.e. the combination of a consolidated government system with the autonomy and responsibility of Russian federal subjects, ensuring the unity of the public service system, and compliance with the constitutional delimitation of ambits and powers between the federal authorities and the authorities of the Russian federal subjects;

d) equal access of citizens to public service;

e) the uniform legal and organisational principles of public service, including the fact that a uniform approach towards the organisation of public service is determined by legislation;

f) the interrelation of public service and municipal service;

g) the transparency of public service and its accessibility to public monitoring, the provision of the public with unbiased information on the activities of public servants;

h) the professionalism and competence of public servants; and

i) the protection of public servants from improper interference with their professional 
service activities by both government authorities or officials and private individuals or legal entities.

In contrast to many foreign countries, Russian legislation does not expressly state the principles of science-based activities, democracy and morality. These principles result from the Constitution of the Russian Federation and from the fundamental understanding that a strong nation is not one where the government controls everything, but one where the law, social justice and humanism prevail.

Seven key principles of public life are legally established in the UK: selflessness, integrity, objectivity, accountability, openness, honesty, leadership. The United States traditionally applies the principles of the merit system, which include recruitment from all strata of the US society, equal treatment of applicants irrespective of their political views, gender, race, religion, ethnic or family origin; equal remuneration for equal labour; the protection of officials from high-handedness, favouritism or political coercion. Germany is committed to the principles of strict legal regulations, democracy, political and religious impartiality, official loyalty and responsibility. Brazil focuses on the enhancement of professional skills, the replacement of bureaucrats with managers in the public service, the development of competitive recruitment and contract-based HR technologies, and more efficient centralised management of the public service.

The consistent implementation of these principles, as evidenced by historical experience, provides a quite solid basis for the stability and highly efficient operation of the government. They provide it with the necessary coherence, social, political and legal focus, and ensure the optimum "configuration" of public servants' participation in the exercise of government powers.

The system of public service processes has its own logic and coherence. It is a set of interrelated and logically structured acts and decisions associated with the recruitment, appointment, evaluation, improvement and rotation of public servants, their professional development and promotion. In structural terms, the public service processes include:

- the preparation of administrative regulations and job descriptions, a sort of "models" for work relationships and positions within the public service system. The job description states the basis for appointment and working conditions with respect to the relevant position, determines the rights, duties and responsibility of the employee, any qualifications required, the rules and procedures for the doing of any legally binding acts by the employee, any performance criteria or indicators;

- the statutory determination of any conditions and establishment of any legal facts, subject to which a person may be considered as a candidate for entering public service. Recruitment must be based on four units of criteria: the formal/questionnaire-based unit, the social and demographic unit, the political and ideological unit and the skills/qualifications unit. The basic conditions for entering public service are as follows: the citizenship of the Russian Federation; an age above 18; the knowledge of the official language; fitness in terms of education and work experience in positions according to the person's core skills and/or with government or municipal bodies, as well as health;

personnel evaluation in terms of professional and personal fitness for their work as part of the staff of government bodies. The purpose of such evaluation is to determine whether the relevant employee complies with the established qualification requirements with respect to his or her position, the status of the government body, the specific field or industry to which the body belongs, the class of the position, and its place in the organisational chart of the staff;

the filling of vacancies in public service, i.e. the appointment to a position by an appropriate legal act to be issued by the relevant government body, the execution of an employment contract, and setting a trial period. If an employee lacks an appropriate service grade, than the employee must pass a qualification examination and be assigned such a service grade after the completion of the trial period;

the exercise of official duties as public servant. In this regard, the service process is equivalent to the performance of job functions and constitutes the principal content of public service;

the provision of incentives for personnel development by assigning service grades, diplomatic ranks, military and special ranks, promotion on the basis of personal achievements and merits, internal audits and conflict investigations, disciplinary measures for any official misconduct, failure to perform or improper performance of official duties, and, most importantly, rewards for highly efficient service;

the provision of a favourable social and living environment for successful service, including labour protection, the availability of schools and kindergartens, fitness and cultural services, the provision of any necessary financial and physical resources; and 
- the termination of public service.

The public service of the Russian Federation has not developed yet into an organically integrated, well-balanced and socially efficient institution to date. In terms of optimisation, professionalism, the quality of performance of its administrative functions, and its ethic foundations, its evolution is still underway. The process of its adaptation to the new social, political and economic conditions has not stopped; on the contrary, it becomes ever more active.

The scientific basis for this process is the "developing approach" and the implementation of the ideas related to the "new culture of public service", which were once stated by D. Osborne and T. Gaebler: instead of drifting with the tide, to rule with hands firmly on the helm of the government ship; to let citizens to show their initiative in addition to administering, regulating and providing public services; service activities must be determined not by formal rules, but primarily by the public interest and citizens' demand; the transparency of public service; the results achieved, rather than procedures or budgetary expenditures, must be the principal criterion; one should invest more in prevention than in the remediation of longlasting problems [15].
The measures stipulated in the "Key Guidelines for Public Service Development in the Russian Federation for 2016-2018" (promulgated by Edict No. 403 of the Russian Federation President, dated August 11, 2016) will help turn our public service into an efficient bureaucracy. And these measures are not minor but significant. They include measures involving stricter delimitation of powers among government bodies and increase in their responsibility; decentralisation of administrative units in order to strengthen their focus on quality and efficiency; enhancement of the public servant's professional prestige; modernisation of the personnel development system in order to increase the motivation of employees for continuous professional development; an updated structure of remuneration and benefits for public servants. The task of de-bureaucratising internal operations in public service and public administration is equally relevant, especially as regards the implementation of electronic personnel document circulation and new methods for evaluating the effectiveness of any activities to prevent corruption or other misconducts. Furthermore, it is planned to diversify the human resources of the public service by recruiting the most talented, skilled and diligent specialists enjoying public trust.

\section{References:}

1. Atamanchuk, G.V., 2008. Sushchnost' gosudarstvennoi sluzhby: istoriya, teoriya, zakon, praktika. Monografiya. [The Essence of Public Service: History, Theory, Law, Practice. A monograph]. Moscow.

2. Gosudarstvennaya sluzhba. Kompleksnyi podkhod: uchebnik. Otv. red. A. V. Obolonskii [Public Service. A Comprehensive Approach: a textbook. Ed. by A.V. Obolonsky]. Moscow, 2009.

3. Grazhdan, V.D., 2011. Gosudarstvennaya grazhdanskaya sluzhba [Public Civil Service]. Moscow.

4. Engibaryan, R.V., 2007. Konstitutsionnoe razvitie v sovremennom mire. Osnovnye tendentsii. Monografiya [Constitutional Development in the Modern World. Key Tendencies. A monograph]. Moscow.

5. Ignatov, V.G., Okhotskii, E.V., Ponedelkov, A.V., 2006. Organizatsiya gosudarstvennoi sluzhby Rossiiskoi Federatsii. Monografiya [Organisation of Public Service in the Russian Federation. A monograph]. Rostov-on-Don.

6. Kazantsev, N.M., 1999. Publichno-pravovoe regulirovanie gosudarstvennoi sluzhby: institutsional'no-funktsional'nyi analiz. Monografiya [Public Law Regulation of Public Service: an Institutional and Functional Analysis. A monograph]. Moscow.

7. Korkunov, N.M., 1909. Russkoe gosudarstvennoe pravo. Tom I. Vvedenie i obshchaya chast' [Russian Government Law. Vol. I. Introduction and General]. St. Petersburg.

8. Kupriyashin, G.L., 2012. Modernizatsiya gosudarstvennogo upravleniya: instituty i interesy. Nauchnye issledovaniya [Modernisation of Public Administration: Institutions and Interests. Scholarly Studies]. Moscow.

9. Kupriyashin, G.L., Solov'ev, A.I., 2013. Teoriya i sovremennye mekhanizmy gosudarstvennogo upravleniya. Ucheb. posobie [The Theory and Contemporary Mechanisms of Public Administration. A textbook]. Moscow.

10. Leoni, B., 2008. Svoboda i zakon. Per. s angl. V. Koshkina, pod red. A. Kuryaeva [Freedom and the Law. Translated from English by V. Koshkin, ed. A. Kuryaev]. Moscow.

11. Okhotskii E.V., 2002. Gosudarstvennaya sluzhba v parlamente: Otechestvennyi i zarubezhnyi opyt. Monografiya [Public Service in Parliament: Russian and International Experience. A monograph]. Moscow.

12. Okhotskii E.V., 2011. Gosudarstvennyi sluzhashchii: status, professiya, prizvanie : uchebno-metodicheskii kompleks [Public Servant: Status, Occupation, Vocation: a Teaching Package]. Moscow. 
13. Putin V.V., 2017. Poslanie Federal'nomu Sobraniyu Rossiiskoi Federatsii. 1 marta 2017 goda [Address to the Federal Assembly of the Russian Federation. March 1].

14. Putin V.V., 2005. Poslanie Federal'nomu Sobraniyu Rossiiskoi Federatsii. 26 aprelya 2005 goda [Address to the Federal Assembly of the Russian Federation. April 26].

15. Osborne D., Gaebler T., 1992. Reinventing Government. Addison-Wesley Publ. Co.

16. Pfifiner L.M., Presthus R., 1960. Public Administration. New York: The Ronald Press Co.

17. Stewart D.W., 1995. An Ethical Framework for Decision Making. Gosudarstvennaya sluzhba. Voprosy etiki. Zarubezhnyi opyt [Public Service. Ethical Aspects. Foreign Experience]. Moscow.

18. Wilson W., 1887. The Study of Administration. American Political Science Quarterly. Vol. 2. No. 2 (June, 1887).

\section{ОРГАНИЗАЦИЯ ГОСУДАРСТВЕННОЙ СЛУЖБЫ В РОССИИ НА СОВРЕМЕННОМ ЭТАПЕ: ОРИЕНТАЦИЯ НА НОВОЕ КАЧЕСТВО УПРАВЛЕНИЯ}

Введение. В статье представлен системный анализ важнейших сущностных характеристик и организационных основ государственной службы современной России и ряда зарубежных государств в контексте сложившихся реалий и перспектив институциональных, структурноуправленческих и кадровых преобразований государственного аппарата. В статье дается характеристика основных составляющих, характеризующих организационную сторону государственной службы, подчеркивается, что модернизация государственного аппарата для современной действительности имеет особое значение, прежде всего в силу того, что проводится она $b$ исторически переломный для мирового, $b$ том числе российского общества период. Отсюда задача формирования у государственных служащих современной «культуры изменений», умения не разрушать, а создавать и приумножать, сохраняя все лучшее, что накоплено историеи государственного строительства и публичного управления, приводить в действие новое и более эфорективное, обеспечивая не революиионнопрерывистый, а плавный созидающий переход от первого ко второму.

Авторы определили понятие «организация государственной службы», выделили в ней целыи ряд организационно и функционально взаимосвязанных подсистем, доказывают, ито эфффективно задачи модернизации и сочииалього обновления могут быть реализованы лишь стабильным, хорошо структурированным, высокопрофессиональным государственным аппаратом, высокоэффрективной, хорошо организованной и авторитетной государственной службой. Государственная служба - это многомерное пространство, каждый элемент которого имеет свой статус, свои отличительные черты и признаки, закрепленные соответствующими общегосударственными установлениями, нормами регионального законодательства и правилами ведомственно-корпоративного регулирования. Характеризуется целым рядом отличительных черт. Прежде всего это институт всеобщих правовых регуляций, исполняемых в бесспорном порядке, это профессиональная служебная деятельность, которая непосредственно связана с процессом реализации Властных полномочий государства, организуется на постоянной, профессиональной, бозмездной основе в соответствии с принципами демократизма, законности, федерализма, социальности и гуманизма.

Материалы и методы. Теоретикометодологической основой исследования послужил диалектико-материалистический подход к анализу общественных явлений, правового регулирования и стратегического управляюшего воздействия на них. Использован широкий набор методов научного анализа политических и соииальных явлений: сравнительноправовой, формально-логический, конкретноисторический, системно-функциональный.

Результаты исследования. В системе координат «развивающегося подхода» и реализаиии идеи «новой культуры государственной службы» авторами обоснованы меры по дальнейшему реформированию государственной службы, предусматривающие более строгое разграничение полномочий аппаратных структур и повышение их ответственности; децентрамизацию административных единии с большей их ориентацией на качество и эффрективность; дебюрократизацию внутриаппаратной государственно-служебной и государственноуправленческой деятельности; повышение престижа профессии государственного служащего; модернизацию системы профессионального развития служащих с точки зрения большей мотивации работников к непрерывному профессиональному развитию; обновление структуры денежного содержания и системы материального стимулирования государственных служащих. 
Охотский Евгений Васильевич, доктор социологических наук, профессор кафедры государственного управления и права факультета управления и политики МГИМО МИД России

\section{Ключевые слова:}

государство, государственная служба, демократизм, законность, модернизация, организация, принципы, профессионализм, система, структура, эффективность
Березко Владимир Эдуардович, кандидат юридических наук, доцент кафедры государственного управления и права факультета управления и политики МГИМО МИД России

\section{Keywords:}

state, public service, democracy, legality, modernisation, organisation, principles, professionalism, system, structure, efficiency

\section{Литература:}

1. Атаманчук Г.В. Сущность государственной службы: история, теория, закон, практика. Монография. M., 2008.

2. Государственная служба. Комплексный подход : учебник / Отв. ред. А. В. Оболонский. М., 2009.

3. Граждан В.Д. Государственная гражданская служба. М., 2011.

4. Енгибарян Р.В. Конституционное развитие в современном мире. Основные тенденции. Монография. M., 2007.

5. Игнатов В.Г., Охотский Е.В., Понеделков А.В. Организация государственной службы Российской Федерации. Монография. Ростов н/Д., 2006.

6. Казанцев Н.М. Публично-правовое регулирование государственной службы: институционно-функциональный анализ. Монография. М., 1999.

7. Коркунов Н.М. Русское государственное право. Том І. Введение и общая часть. СПб., 1909.

8. Куприяшин Г.Л. Модернизация государственного управления: институты и интересы. Научные исследования. M., 2012.

9. Куприяшин Г.Л., Соловьев А.И. Теория и современные механизмы государственного управления. Учеб. пособие. М., 2013.

10. Леони Б. Свобода и закон / Пер. с англ. В. Кошкина, под ред. А. Куряева. М., 2008.

11. Охотский Е.В. Государственная служба в парламенте: Отечественный и зарубежный опыт. Монография. M., 2002.

12. Охотский Е.В. Государственный служащий: статус, профессия, призвание: учебно-методический комплекс. M., 2011.

13. Путин В.В. Послание Федеральному Собранию Российской Федерации. 1 марта 2017 года.

14. Путин В.В. Послание Федеральному Собранию Российской Федерации. 26 апреля 2005 года.

15. Osborne D., Gaebler T. Reinventing Government. Addison-Wesley Publ. Co., 1992.

16. Pfifiner L.M., Presthus R. Public Administration. New York: The Ronald Press Co., 1960.

17. Stewart D.W. An Ethical Framework for Decision Making // Государственная служба. Вопросы этики. Зарубежный опыт. М., 1995.

18. Wilson W. The Study of Administration // American Political Science Quarterly. 1887. Vol. 2. No. 2 (June, 1887). 